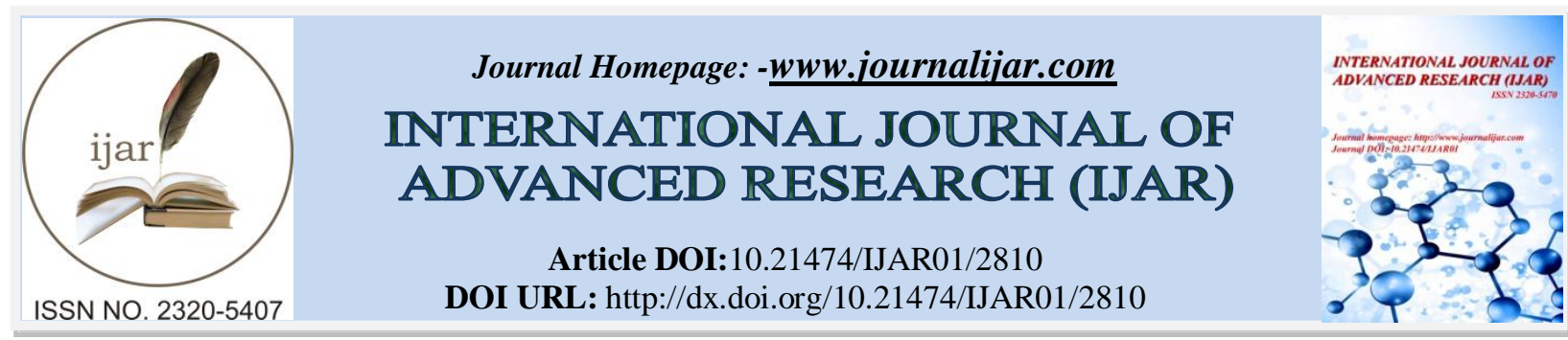

RESEARCH ARTICLE

\title{
BACTERIA EXTRACT ACTIVITY ASSOCIATED WITH SPONGESHaliclonasp.2 ANDAxinellid sp.AS ANTIBACTERIAL.
}

Endang Sulistyarini Gultom ${ }^{1}$, Dwi Suryanto ${ }^{2}$, Erman Munir $^{2}$ and Diky Setya Diningrat ${ }^{1}$.

1. Biology Department, FMIPA, Medan State University. Jl. Willem Iskandar Pasar V, Medan 20221, Indonesia.

2. Biology Department, FMIPA, University of North Sumatera. Jl. Bioteknologi 1, Medan 20155, Indonesia.

\section{Manuscript Info}

Manuscript History

Received: 15 November 2016

Final Accepted: 17 December 2016

Published: January 2017

Key words:-

Haliclona sp.2 andAxinellid sp., antibacterial, thin layer chromatography, sponges.

\begin{abstract}
Isolation of bacteria for antibacterial activity was conducted on spongeassociated marine bacteria, Haliclona sp.2 and Axinellid sp.from Ngge Island, Sibolga. Seventeen isolates were obtained from the two sponges. Based on antibacterial test, 11 isolates $(64 \%)$ were potential as antibacterial, whereas 6 isolates $(35 \%)$ were not indicatedas antibacterial. Isolate $\mathrm{H} 2, \mathrm{~A} 1$, and $\mathrm{A} 2$ with broad spectra of antibacterial activity were further separated for extraction of secondary metabolites. Based on screening results of isolates, etil acetate extract of isolate $\mathrm{H} 2$, A1, A2 and n-hexana extract of isolate A2 displayed antibacterial against Staphylococcus aureusandEscherichia coli, whereas methanol extract A2 was only able to inhibit the growth of Escherichiacoli. For bioactive compound test, EH2, EA1 and EA2 were positive for alkaloid, whereas HA2 and MA2 were positive for alkaloid and saponin. Based on purification of secondary metabolite using Thin Layer Chromatography (TLC), there were22 fractions with solvents of different polarities. Screening of antibacterial activity for isolate extract fractions showed thatMA2 of fraction 2 had a strong inhibitive effectagainst E.coli and S. Aureusabout $10,15 \mathrm{~mm}$ and $9,95 \mathrm{~mm}$ consecutively. The antagonistic activity of EH2of fraction 3 against $S$. aureusandE.coliwere about $7,05 \mathrm{~mm}$ and $7,45 \mathrm{~mm}$ consecutively, whereas EA1 of fraction 3 was about $6,55 \mathrm{~mm}$ againts $P$. Aeruginosa. The results of phytochemical secondary metabolite of isolate extract fractions showed that MA2 of fraction 2 and MA2 of fraction 3 werepositive for saponin, while EH2 fraction 3 and EA1 fraction 3 were positive for alkaloid. Bacteria associated with sponges Haliclona sp.2 and Axinellidsp. had activity as antibacterial against bacteria $S$. aureus, E. coli and P. aeruginosa.
\end{abstract}

Copy Right, IJAR, 2016,. All rights reserved.

\section{Introduction:-}

Pathogenic microba has been considered as a crucial problem in human healthy and can cause various diseases. The use of chemical compounds that acts as antibacterial such as unrational antibiotic to treat various diseasescaused by pathogen, could make a negative side effect even it could cause bacteria becomes resistance againts specific 
antibacterial. In order to overcome this issue, it is important to explore antibacterial originated from bioactive compounds of plants, animals and microorganisms.

Sponge is one of corral reef componentsthat has a potential bioactive but not has been explored. Exploration of sponges as bioactive source has been reported in various researches. However, the use of secondary metabolites produced by bacteriaassociated with sponges as antibacterial source is more beneficial as compared to isolation from its host. The excessive exploration of sponges to produce new bioactive could cause overfishing that could damage marine ecology. In addition to the growth of sponges that is relatively slow will inhibit the biomass availability as source of secondary metabolites. Therefore, the use of bacteria associated with sponges will be efficientbecause the bacteria could be cultured in laboratory and could be multiplied in relatively fast (Abubakar et al., 2011).

Capability of sponges in producing bioactive compounds due to its symbiosis with bacteria. The relationship sponges with bacteria will produce secondary metabolite as a form of defense against natural enemies such as predators, pathogenic microorganisms, competitor and fouling organisms (Taylor et al., 2007). Thisrelationship includes a generous supply of nutrients through metabolism translocation such as nitrification, nitrogen fixation, photosinthesis, and an enhancement of chemical defenses. Due to the roles,symbiotic bacteria with sponges is estimated has a great potential on theproduction of bioactive compounds isolated from sponges (Kennedy et al., 2008).

Some researchers of marine explore a new bioactive compounds from sponge-symbiotic bacteria. Peptide was isolated from both sponge Hyatella sp. and an associated Vibrio sp. that has antibacterial activity (Taylor et al., 2007).New metabolites from sponge-symbiotic bacteria contribute tohas antibacterial and antiplasmodial activity. Extract of $\mathrm{n}$ - hexana and ethyl acetat from 4 (four) potential species of bacteria isolated from sponges haveantibacterial activity(Dash et al., 2009; Inbaneson et al., 2012). One of antibacterial compounds was isolated from bacteria Pseudovibrio spp.associated with sponges Axinella dissimilis(Halloran et al.,2011).

Bacteria associated with sponges include representative of the Proteobacteria, Bacteroidetes, Firmicutes, and Actinobacteria(Taylor et al., 2007). Selvin et al., (2009) reported that potential microbe which produce active compounds areCyanobacteria, Fungi and Actinomycetes. The active compound resulted by sponge Dendrilla nigra associated with Actinomycetes Nocardiopsis dassonvillei MAD08 was as antimicrobial compoundagainst gramnegative bacteria (Staphylococcus aureus MTCC 2940, Staphylococcus aureus MTCC 96, Micrococcus luteus MTCC 106, Rhodococcus rhodochrous MTCC 265) and gram-positive bacteria (Vibrio cholerae PC6, Pseudomonas aeruginosa MTCC 2453 and Escherichia coli MTCC 2939).Some bacteria isolates associated with sponges Jaspis sp.are antibacterial because of inhibiting the growth of Staphylococcus aureus, Vibrio harveyii, Escherichia coli, Pseudomonas aerogenosaandEPEC K-11 (Abubakar et al., 2011). Correlation between production of antibacterial compound by bacterial symbiontswith sponges has been investigated by NarsinhaandAnil (2000), that antibacterial compound produced by bacterial symbionts such asó proteobacterium MBIC 3368, Idiomarina sp andPseudomonas sp. were very affected by protein recombinant of Suberitas domuncula as host. This research confirmed that there is a collaboration in biosinthesis of secondary metabolite between symbion microbe and sponges.

Based on various results research, an investigation for sponge-associated bacteria as antibacterial which easy to be cultured, was needed to be conducted. The isolation results will be tested for antibacterial activity against Staphylococcus aureus, Pseudomonas aeruginosa and Escherichia coli.

\section{Materials and Methods:-}

\subsection{Sample collection}

The marine spongeswere collected off from NggeIsland, Sibolga by SCUBA diving at 2-10 m. Temperature, salinity, and $\mathrm{pH}$ were determined at the moment of sample collection. Sponges samples were collected as needed then put into plastic bag filled marine water and oxygen then put into cool box. Sponges were identified at Laboratory of Marine Biology of Fishery Faculty of Riau University.

\subsection{Extraction of Secondary Metabolite from Potential Bacterial Isolate}

Suspension was made with turbidity justified with Standard of McFarland $10^{8} \mathrm{CFU} / \mathrm{ml}$, then spreaded with cotton swab on the surface of NA media. Some suspensions were made on petri disk and incubated for 5- 6 days at $25^{\circ} \mathrm{C}$. Bacterial cultures which obtained were cut into small pieces then put into erlemeyer $500 \mathrm{ml}$ then it was added \pm 150 $\mathrm{ml}$ solvent n-heksana, macerated for $3 \times 24$ hours. It was filtered with Whatman 42, thus resultedmacerat and residual. Residual was reextracted with ethyl acetate and filtered. With the same way, residual was extracted with methanol. Each macerat was centrifuged with $3000 \mathrm{rpm}$ for 15 minutes, thus result supernatant. Then the 
supernatant was separated with each their solvent by using rotary evaporator at $45^{\circ} \mathrm{C}$. It was obtained extract $\mathrm{n}-$ heksana, ethyl acetate and methanol secondary of potential bacterial isolate(Nofiani et al., 2009). The series levels of extraction was shown in appendix $4 \mathrm{a}$.

\subsection{Screening Bacterial Extract for Antibacterial Activity}

Bacterial suspension ofStaphylococcus aureus, Pseudomonas aeruginosa andEscherichia coli were as tested bacteria.For extract activity test, suspension of test bacterial culture was prepared by inoculation each them into nutrient broth media and incubated for 24 hours at $25^{\circ} \mathrm{C}$. Activity test conducted by inoculated $200 \mu \mathrm{l}$ suspension of bacterial test that was rejuviniled into agar media and spread out with hockey stick thus test bacterial suspension mix on media surface. Then it was kept for a few moment to let the bacterial test fuse with the media. Then it was put into oxoid disk that was droped with $10 \mu \mathrm{l}$ of extract $-\mathrm{n}$ - hexana secondary metabolite potential bacteria into agar media that was inoculated with Staphylococcus Aureus, Pseudomonas aeruginosa andEscherichia coli. Then incubated for 24 hours at $25 \mathrm{oC}$ and investiged inhibition zone formed with vernier caliper. The same treatment was applied against extract ethyl acetate and methanol of secondary metabolites of potential bacteria.

2.4 Identification of Chemical Compound in Potential IsolateExtract n-Hexana, Ethyl acetate and Methanol. Preliminary test of secondary metabolite was carried out on each potential isolate extract. $5 \mathrm{ml}$ aquadest and chloroform were added into the extract then mixed strongly and let it for a few minute until two layers formed. Water layer was used for metabolite secondary assay of flavonoid, fenolik, and saponin whereas Chloroform layer was used for terpenoid and steroid (Harbone, 2006).

\subsection{Identification and Isolation Secondary MetabolitePotential Isolate Extract by Preparative Thin Layer Chromatography.}

Chamber was saturated with raising solvent by covered chamber with filter paper, then raising solvent was put into chamber until all filter paper throughly wet by the solvent. Extract solvent contained secondary metabolite of potential isolate spottedon preparative TLC with $20 \times 20 \mathrm{~cm}$ until the plate saturated by extract solvent $(1.5 \mathrm{~cm}$ from under line), plate was let until dry for \pm 15 minutes. Previous plate was marked upper and down limit. Then plate put into chamber that was saturated and eluted until the solvent reached upper limit line. Node formed was checked under UV light and pattern formed of node was drawn with pencil. Then the pattern was scraped with spatula and each node was separated into vialfurthemore was washed and separated from its silica. Compounds that were separated from the silica, the solvents was volatiled and antimicrobe test was conducted.

\subsection{Screening of Antibacteria Activity Fraction of n-hexana, Etil Acetate and Methanol of Potential Bacteria Isolate.}

Bacterial suspensions of Staphylococcus aureus, Pseudomonas aeruginosa and Escherichia coli were as bacterial test. For screening, the suspensions were inoculated nutrient broth media and was incubated for 24 hours at $25^{\circ} \mathrm{C}$. Identification of antibacterial activity was used disc diffusion assay(Bauer et al., 1996).200 $\mu$ l suspensions that already rejuveniled were inoculated into nutrient agar media and spreaded out with hockey stick, thus bacterial suspension test was mixed throughly on surface media.

Then it was waited for a few minute until the bacterial suspension fused with media. Then it placed on the empty oxoid disk that already spotted with $10 \mu \mathrm{l}$ fraction $\mathrm{n}$ - hexana secondary metabolite of potential bacteria into media NA that was inoculated with bacteria $S$. aureus, $P$. aeruginosa and E. coli. The culture was incubated for 24 hours at $25^{\circ} \mathrm{C}$ and inhibition zone formed was observed withvernier caliper. The same treatment was applied on fraction ethyl acetate and methanol of secondary metabolite of potential bacteria. Furthermore, result of screening antibacterial activity was tested for phytochemical identification of potential isolateextract fraction.

\section{Results and Discussions:-}

\subsection{Sponges Characteristic}

Sponges were takenfrom Ngge Island, Sibolga from 2- $10 \mathrm{~m}$ with purposive sampling method by scuba diving. Determination ofpH with $\mathrm{pH}$ - meter shown that $\mathrm{pH}$ of marine water of sponge sampling was 7.5; salinity $30 \%$ and temperature $29^{\circ} \mathrm{C}$. Collecting sponges was located based on GPS that were N. 01. 39. 001. E.098.47.661. N. 01. 34. 379. E. 098. 45. 251. N. 01.34. 361. E.098. 45. 252. N. 01. 35. 419. E. 098. 41. 831. Measurement of sampling location condition was to create suitable environment for symbion bacterial test thus symbiont bacteria was able survive to live. Sponges sample were taken as needed then put into plastic bag that filled with marine water and oxygen and then put into cool box. The sponges from Ngge Sibolga were Haliclona sp.2 and Axinellid sp. 
(Figure4.1).In addition, Haliclona sp.2 has oscula on each branch and blue colour, whereas Axinellid sp.has a shape like fan,yellowness, and oscula on whole surface (Gosliner et al, 1996)

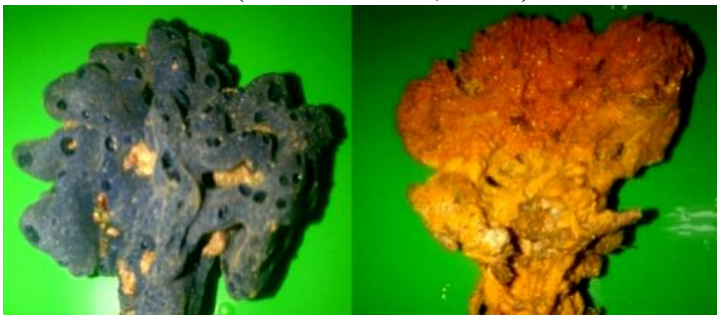

Figure 4.1. Sponges (a) Haliclona sp.2 and (b) Axinellid sp.

\subsection{Isolation and Purification of Symbiont Bacteria}

Based on isolation results, there were 17 isolates from mesophyl of the two sponges that consisted of 8 isolates of Haliclona sp.2 and 9 isolatesofAxinellid sp. (Appendix 2b).Bacteria in mesophyl was bacteria that has a similarity secondary metabolitewith the sponges. Thiel et al. (2007) had discovered bacteria in large amount on sponges mesophyl Chondrilla nucula. The bacteria was isolated based on morphology, size and shape of colony. Seventeen isolates were isolated based on color and colony shape (Table 11). It showed possibility many differences of activity for each isolate thatused for further test. Isolation and purification of symbiont bacteria could be shown as follows: Table 1. Characterization morphology of bacterial isolate that was isolated based on colour and shape on sponges Haliclona sp.2 andAxinellid sp.

\begin{tabular}{|l|l|l|l|l|l|}
\hline Species & $\begin{array}{l}\text { Isolate } \\
\text { Code }\end{array}$ & Colony form & Color & Elevation & $\begin{array}{l}\text { The edge of the } \\
\text { colony }\end{array}$ \\
\hline Haliclona sp.2 & H1 & Round & Yellow & Flat & Entire \\
\hline & H2 & Round & Beige & Flat & Entire \\
\hline & H3 & Bobbin & Beige & Raised panel & Round \\
\hline & H4 & Round & Yellow & flat & Wave \\
\hline & H5 & Round & Beige & Flat & Entire \\
\hline & H6 & Bobbin & Yellowish beige & Arise & Entire \\
\hline & H7 & Round & Beige & Flat & Irregular \\
\hline & H8 & Irregular & Beige & Flat & Curly \\
\hline Axinellid sp. & A1 & Round & Beige & Flat & Wave \\
\hline & A2 & Bobbin & Yellow & Arised panel & Entire \\
\hline & A3 & Irregular & Beige & Panel & Curly \\
\hline & A4 & Round & Beige & Flat & Entire \\
\hline & A5 & Round & slightly yellow & Flat & Entire \\
\hline & A6 & Round & Beige & curve & Entire \\
\hline & A7 & Root like & Beige & Flat & Curly \\
\hline & A8 & Irregular & Beige & Flat & Blade \\
\hline & A9 & Irregular & Beige & Flat & \\
\hline
\end{tabular}

Various microorganisms associated with sponges. For instance, unicellularalgae, Cyanobacteria, dinoflagellatesandArchaea. Among these microorganisms, bacteriaare the most dominant that constituted up to40\% of the biomass or $60 \%$ of the tissue volume of certainsponge species (Lee et al, 2006). According to Vasanthabharathi et al., (2012), bacterial densitythat associated with sponges H. cribriformis, S. carnosa, C. diffusa andS. officinnalis Var. ceylonensiswas in the range was $13 \times 10^{3}-1.6 \times 10^{7} \mathrm{CFU} / \mathrm{g}, 6.77 \times 10^{3}-1.5 \times 10^{7} \mathrm{CFU} / \mathrm{g}$, $7.68 \times 10^{3}-1.1 \times 10^{7} \mathrm{CFU} / \mathrm{g}$ and $2.69 \times 10^{3}-1.4 \times 10^{7} \mathrm{CFU} / \mathrm{g}$.In Taylor et al. (2007)described that associations between sponges and microorganisms can be maintained by two ways thas is filter feeding which microbes can be recruited from the surrounding water to the sponges (horizontal transmission) or by reproductive stages (vertical transmission). In vertical transmission, oocyte from the adult mesohyl of sponge can phagocytosis to the microbial cellsso bacterial symbiont could be found on embryo/ sponges larva.

Differentiation of diversity and number of bacterial isolates of each kind of sponges might be due to isolation technic and growth media that used for isolation bacteria associated with sponges. Nutrient contents of culture media would affect bacterial growth. According to Haloran et al. (2011),there were73 from the marine sponges 
Axinella dissimilis, Polymastia boletiformis and Haliclona simulans and identified as being Pseudovibrio spp. by 16S rRNA genesequencing and phylogenetic analysis.Radjasa et al. (2008) reported, there were32 bacterial isolates from sponges Haliclonasp.in North Java Sea. Murniasih and Rasyid (2010) also reported that there were 75 bacterial isolates from sponges Theonella sp., Aaptos sp., Melophlus sarassinorum.,Callyspongia sp., Ircinia sp., Stylissa flabeliformes, Lisoclinum sp., andClarithria sp. by direct plating. Abdullah (2006) also had obtained 7 bacterial isolates associated with sponges Axinella sp. by using marine broth agar media.

Symbiont bacteria producea wide array of secondary metabolitesas antibacterial(Leeet al., 2001). Although the mechanism of association between sponges and bacteria is not known well, the association could produce secondary metabolite. Secondary metabolite production by sponges has similarity with microorganisms associated with sponges itself, include bacteria (Radjasaet al., 2007).In addition, bacteria associated with organisms have probability an interaction with the host organisms (Lee et al., 2001). The biochemical interaction make a possibility that symbiont bacteria produces the same bioactive compound with its host. In Taylor et al. (2007), was explained that bacteria symbiosis with sponges are able to photosynthesis, oxidize methane, nitrification, nitrogen fixation, sulphat reduction and dehalogenase.

\subsection{Extraction of Secondary Metabolite from Potential Bacteria}

Extraction of secondary metabolite was carried out by maceration(Appendix 4b). In Nofiani et al. (2009) was described that maceration can produce intracelluler antimicrobe compound thus bacterial cell need to be broken to obtain antibacterial compounds. Different polarity of solvents in macerationwere $\mathrm{n}$ - heksana (nonpolar), ethyl acetate (semipolar) and methanol (polar). According to Dash et al. (2009) polarity differences on solvent used in order to isolate secondary metabolite and identification of following stage.

Extraction of secondary metabolites with different polarity of solvent was conducted serially. The isolatesfor this stage were determined based on the ability to inhibit some bacteria tests, that were H2, A1 andA2. Then, results of secondary metabolite extraction were extract of n-hexana, ethyl acetate and methanol of potential bacteria isolates. Taylor etal. (2007) described that, secondary metabolites produced by symbiont bacteria is potential as precursor of biosynthesis of sponges metabolite.

\subsection{Screening Activity of Extract Antibacteria of Isolate Potential Bacteria}

Results of screening for antibacteria activity of potential bacteria isolate extract were each isolates of extract ethyl acetate (EH2, EA1 andEA2) and extract $\mathrm{n}$ - hexana A2 showed antagonistic capability against bacteria test $S$. aureus and E. coli.

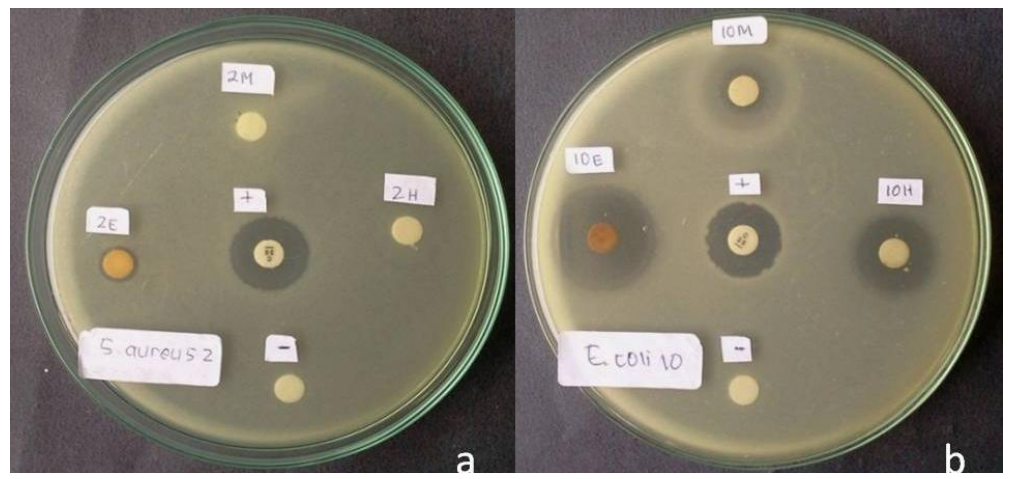

Figure 3. Sampling of antibacterial activity (a) extract ethyl acetate of isolate H2 (EH2) against S. Aureus and(b) Extract n-hexana, ethyl acetate and methanol of isolate A2 (HA2, EA2 and MA2) against E. coli.

Based on screening results of antibacteria activity, $\mathrm{H} 2$ and $\mathrm{A} 1$ were able to inhibit growth of $P$. Aeruginosa, while screening results of secondary metabolite extract showed that both isolates did not perform antibacterial activityagainst $P$. aeruginosa(Table 4.3).Extract hexana and ethyl acetate of isolate A2 (HA2) resulted inhibition zone against $S$. aureus dan $E$. coli(Table 4.3) but not for P. Aeruginosa. For antagonist test of isolate showed that isolate A2 was capable of inhibiting growth of both bacteria $S$. aureusand E. Coli (Tabel 4.3).According to Tinambunan et al. (2012) extract of bacteria associated with sponges with concentration $10 \%$ showed largest zone inhibition of antibacterial activity against $S$. aureus and E. coli. Extract ethyl acetate ethyl acetate of isolate A2 (EA2) had broaspectrum activity because it was capable of inhibiting gram positive and gram negative bacteria and according to David and Stout (1971) it was included as active compound with strong inhibition capacity (diameter of inhibition zone against $S$. aureus and $E$. coli were $20,05 \mathrm{~mm}$ and $23,00 \mathrm{~mm}$ consecutively). 
Extracts of three isolates ( $\mathrm{H} 2$, A1 and A2) showed negative results against bacteria test P. aeruginosa. While extract MA2 only capable of inhibiting growth of bacteria test E. coli (Table 4.3). This might due to MA2 was suggested contain secondary metabolite that was facilitated to disturb permiability cell membrane of gram negative bacteria thus cell bacteria lysis. In Nofiani et al. (2009) explained that there are some suggestions that caused bacterial isolates did not show antibacterial activity namely (1) isolat has gene code formation secondary metabolite compound but it is not expressed at normal condition and will be expressed when it is induced previously; (2) symbiont bacteria produces antimicrobe compound intracellularly but it does not have antibacteria activity against bacteria test. Radjasa et al. (2007) stated that the production of secondary metabolite from the sponges has similar with microorganisms associated with sponges. It indicate that the production of secondary metabolite from simbiont bacteria is affected by host sponge. Thus when simbiont bacteria is isolated from host sponge, it will affect secondary metabolite as antibacteri.

\subsection{Test Chemical Compound of Extract n-Hexana, Ethyl Acetate and Methanol of Potential Isolate}

Identification of secondary metabolite content is an important initial step in searching new bioactive compound from natural material and as precussor for synthesis new medicine or as a medicine prototype with certain activity (Harborne, 2006).Capability of antagonistic activity against bacteria test is due to presence of secondary metabolite produced by isolate of symbiont bacteria. Test component of extract chemical compounds, n-hexana, ethylacetate and methanol of isolate potential bacteria was conducted as initial test to investigate the characteristic of secondary metabolite.Alkaloid was positive for each extract ethylacetate isolate ( $\mathrm{H} 2, \mathrm{~A} 1$ and $\mathrm{A} 2)$ by useddragendorf reagent and resulted red sediment (Appendix 5b).Furthermore, extract n-hexana and methanol of isolate A2 were positive contained alkaloid and sapoin (Table 4.4). Alkaloid and sapoin indicated antagonist ability against bacteria test (Tabel 4.3) whereas identification other secondary metabolite such as steroid, terpenoid, fenolic and flavonoid showed negative result.

\subsection{Identificationof SecondaryMetabolites in Potential Bacteria Isolates by using Thin Layer Chromatography(TLC) Preparative}

Identification secondary metabolite compounds of symbiont bacteria was conducted with TLC (Penesyan et al., 2011). Based on preparative TLC results were found 22 fractions observed under UV from five extracts (EH2, EA1, EA2, HA2 and MA2) with different polarity. Movement phase was used to eluted the samples and variated based on polarity gradient (Yuhernita, 2011).Movement phase drained through static phase and carried components of extract potential bacteria isolate. Different component will move with different rate. Based onpreparativechromatographyresults, separation ofcompoundsinextracts of bacteriaisolatesinto pure substanceswere obtained6fractionsinHA2(nonpolar) whileEH2, EA1, EA2andMA2(semipolar andpolar) obtained4fractions for each. (Figure 4).

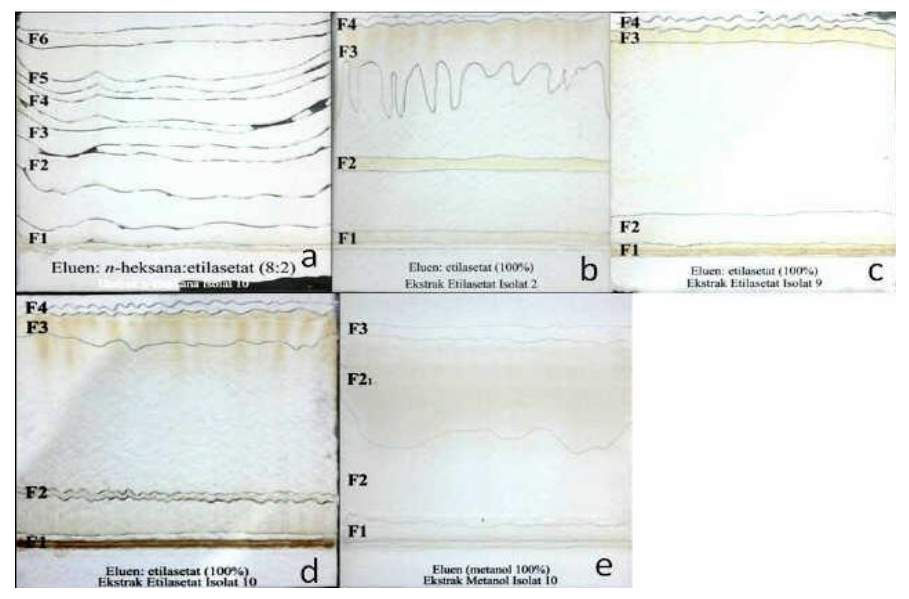

Figure 4.Results of Thin Layer Chromatography (TLC) preparativefor secondary metaboliteof extract potential bacteria isolate. (a) HA2; (b) EH2; (c) EA1; (d) EA2; (e) MA2.

\subsection{Screening Antibacteria Activity on Extract Fraction of Potential Bacterial Isolate}

Secondary metabolite fraction of extract potential bacterial isolate showed antagonist ability against bacteria test. Based on screening results of antibacterial activity, the largest antagonist ability of secondary metabolite extract 
farction was MA2F2 aginst $E$. coliand $S$. aureusbacteria with diameter $10,15 \mathrm{~mm}$ and $9,95 \mathrm{~mm}$ consecutively (Fig.5).MA2 was obtained from sponges Axinellid sp. that contained saponin.

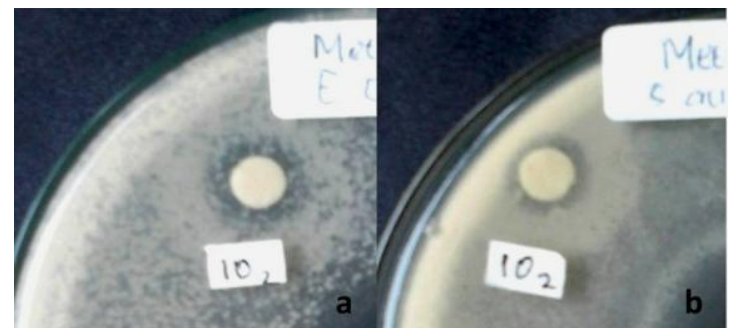

Figure.5. Examples of antibacteria activity of extract methanol of Isolates A2 fraction 2 (MA2F2) against bacteria (a) E.coli and (b) S. Aureus

Antibacteria activity was also found on EH2F3 against bacteria $S$. aureusandE. coli. IsolateH2 was obtained from sponges Haliclona sp. 2 with secondary metabolite alkaloid. Antagonist ability was indicated with the formation clear zone against bacteria $S$. aureusand $E$. coli with diameter 7,05 $\mathrm{mm}$ and 7,45 $\mathrm{mm}$ consecutively. Research about antibacteria activity of sponges genus Haliclona was also conducted previously. Radjasa et al. (2007) stated that symbiont bacteria of sponges Haliclona sp. showed antibacteria activity against some bacteria test, one of them was S. aureuswith diameter $>9 \mathrm{~mm}$.

Screening results of antibacteria activity of extract fraction of Isolate EA1F3 showed clear zonewith diameter $6.55 \mathrm{~mm}$ against P.aeruginosa. This result was different from antibacteria activity screening of isolate extract, where extract isolate EA1 did not have antibacteria activity against $P$. Aeruginosa.Extract fraction screening result of isolate MA2 was also showed differences from extract screening of bacterial isolate. For initial screening, isolate MA2 was only showed antagonistic ability against bacteria E. coli whereas extract fraction screening of bacterial isolate MA2F2 and MA2F3 showed antagonistic ability against E. coliandS. Aureus.

A research conducted by Nofiani et al. (2009) stated that extract methanol of bacteria associated with sponges showed antibacteria activity but based on minimum inhibition concentration value, antimicrobe activity still categorized as weak. Both extract fractions of n-hexana and ethyl acetate of isolate A2 did not show presence of antibacterial activity. This might due to the presence of other secondary metabolites that associatedin each other and this indication has not detected thus capable of producing antibacterial activity against bacteria test. Other factors was the amount of secondary metabolite fraction obtained was small thus it was not capable of inhibiting the bactria test growth.

\subsection{Chemical Compound Assay of Extract Fraction n-Hexana, Ethyl Acetate and Methanol of Potential Bacterial Isolate}

Based on screening results of antibacterial activity extract fraction of EH2F3, EA1F3, MA2F2, and MA2F3 have antagonist ability against bacteria test. Furthermore, test of chemical compound for secondary metabolite was conducted. It showed that MA2F2 and MA2F3 were positive contained saponin while EH2F3 and EA1F3 was positive contained alkaloid.Saponin for MA2F2 and MA2F3 and alkaloid for EH2F3 and EA1F3, have the same result with previous test of secondary metabolite compound. Secondary metabolite such as alkaloid and saponin are potential as antibacterial. According to Zheng (2005), secondary metabolite alkaloid of bacteria associated with sponges Himeniacidon parleve also showed antibacterial activity against $S$. aureus. Antibacteria activity produced by symbiont bacteria of sponges Haliclona sp.2andAxinellid sp are enable competition occur in the sea ecosystem. According to Dash et al (2009), symbiont bacteria which produces antibacterial compound is enable to form colony on the sponges surface. Saponin, tanin and flavonoid are secondary metabolites that have antibacterial activity. Saponin is bioactive compound to increase membran permiability thus cell hemolysis occur, when saponin interacts with bacterial cell, the bacterial cell will be broken or lysis. This could be made as opportunity to develope secondary metabolite for further research (Ganiswarna, 1995).

\section{Conclusions:-}

Based on research results, the conclusion of this research were as this following:

1. Extracts of EH2, EA1, EA2, HA2 and MA2 have antibacterial activity on bacteria S. Aureu,s E. Coli and P. Aeruginosa.

2. Extract of EH2 was very potential against $S$. aureus and E. Coli compared with extracts EH2, EA1, HA2 and MA2. 
3. It was found 4 (four) extract fractions of secondary metabolites (EH2F3, EA1F3, MA2F2 and MA2F3) which have an activity against $S$. aureus, E. coliand $P$. Aeruginosa.

4. Based on phytochemical screening of secondary metabolite fractions (EH2F3, EA1F3, MA2F2 and MA2F3) that has antibacterial activity were alkaloid and saponin.

\section{References:-}

1 Abdullah, A. 2006.Isolasi dan Identifikasi Mikroba Simbion Sponge Axinella sp.Jurnal Ilmu Pertanian Indonesia. 11 (3): 1-5.

2 Abubakar, H., Wahyudi, A.T. and Yuhana, M. 2011. Skrining Bakteri yang berasosiasi dengan Spons Jaspis sp. Sebagai Penghasil Senyawa Antimikroba.Jurnal Ilmu Pertanian Indonesia. 11(3): 1-5.

3 Bauer, A.W., Kirby, W.M., Sherris, J.C. and Turek, M. 1996. Antibiotic Susceptibility Testing By a Standardized Single Disk Method. American. Journal Clinic Pathology. 45: 493-498.

4 Campbell, N.A.andReece, J.A. 2009.Biology $8^{\text {th }}$ Edition. Benjamin Cummings. San Fransisco.

5 Dash, S., Jin, C., Lee, O.O., Xu, Y. Dan Qian, Y.P. 2009. Antibacterial and Antilarval-Settlement Potential and Metabolite Profiles of Novel Sponge-Associated Marine Bacteria.Journal of Industrial.Microbiology Biotechnology.36: 1047-1056.

6 Ginting, E. L., Warouw, V. dan Suleman, R.W. 2010. Aktivitas Antibakteri dari Ekstrak Kasar Bakteri yang Berasosiasi dengan Sponge Acanthostrongylophora sp. Jurnal Perikanan dan Kelautan Tropis. 6(3): 160-163.

7 Gosliner, T.M., Behrens, D.W., and William, G.C., 1996. Coral Reef Animals of the Indo Pacific. Sea Chalengers. Monterey

8 Halloran,J.A.O., Barbosa, T.M., Morrissey, J.P., Kennedy, J., O’ Gara, F. and Dobson, A.D.W. 2011. Diversity and Antimicrobial Activity of Pseudovibrio spp. from Irish Marine Sponges.Journal of Applied Microbiology. 110: $1495-1508$.

9 Harborne, J.B. 2006. Metode Fitokimia: Penuntun Cara Modern Menganalisis tumbuhan. Edisi IV. Kokasih P. dan I. Soediro. (penterjemah). ITB, Bandung: 35.

10 Inbaneson, S.J. andRavikumar, S. 2012. In Vitro Antiplasmodial Activity of Clathria vulpina Sponge Associated Bacteria AgainstPlasmodium falciparum. Asian Pacific Journal of Tropical Disease: 319-323.

11 Irianto. 2008. Petunjuk Praktikum Mikrobiologi Dasar. Laboratorium Mikrobiologi Fakultas Biologi. Universitas Jendral Soedirman Purwokerto. Purwokerto

12 Kennedy, J., Codling, C.E., Jones, B.V., Dobson, A.D.W. and Marchesi, J.R. 2008. Diversity of Microbes Associated with the Marine Sponge, Haliclona simulans, Isolated from Irish Waters and Identification of Polyketide Synthase Genes from the Sponge Metagenome. AppliedEnvironmental Microbiology 10(7): 18881902.

13 Lee, Y.K., Lee, J. H. and Lee, H.K.2001. Microbial Symbiosis in Marine Sponges. The Journal of Microbiology. 39 (4): 254-264.

14 Lee, O.O., Lau, S.C.K., and Qian, P.Y. 2006. Consistent Bacterial Community Structure Associated with the Surface of the Sponge Mycale adhaerens Bowerbank. Microbial Ecology. Volume 52, 693-707

15 Murniasih, T.andRasyid, A. 2010.Potensi Bakteri yang Berasosiasi dengan Spons Asal Barrang Lompo (Makassar) Sebagai Sumber Bahan Antibakteri.JurnalOseanologi dan Limnologi di Indonesia 36 (3): 281-292.

16 Narsinha, L.T. andAnil, A.C. 2000. Antibacterial activity of the sponge Ircinia ramose: Importance of its Surface-Associated Bacteria. Journal of Chemical Ecology. 26(1): 57-71.

17 Nofiani, R., Nurbetty, S. and Sapar, A. 2009. Aktifitas Antimikroba Ekstrak Metanol Bakteri Berasosiasi Spons dari Pulau Lemukutan Kalimantan Barat. Jurnal Ilmu dan Teknologi Kelautan Tropis. 1 (2): 33-34.

18 Pastra, D.A., Melki. and Surbakti,H. 2012. Penapisan Bakteri yang Bersimbiosis dengan Spons Jenis Aplysina sp. sebagai Penghasil Antibakteri dari Perairan Pulau Tegal Lampung. Maspari Journal. 4(1): 77-82

19 Penesyan, A., Tebben, J., Lee, M., Thomas, T., Kjelleberg, S., Harder, T. and Suhelen, E.S. 2011. Identification of the Antibacterial Compound Produced by the Marine Epiphytic Bacterium Pseudovibrio sp. D323 and Related Sponge-Associated Bacteria. Marine Drugs.9: 1391-1402.

20 Radjasa, O.K., Sabdono, A., Junaidi and Zocchi, E. 2008. Growth Inhibition of Medically Antibiotic Resistant Bacteria by Sponge-Associated Bacteria.Journal of Coastal Development.11 (2): 75-80.

21 Radjasa, O.K., Sabdono, A. andJunaidi, J. 2007. Richness of SecondaryMetabolite-Producing Marine Bacteria Associated with Sponge Haliclona sp. International Journal of Pharmacology. 3(3): 275-279.

22 Selvin, J.,Shanmughapriya, S., Gandhimathi, R., Kiran, G.S., Ravji, T.R., Natarajaseenivasan, K. and Hema, T.A. 2009. Optimization and Production of Novel Antimicrobial Agents from Sponge Associated Marine Actinomycetes Nocardiopsis dassonvillei MAD08.Applied Microbiology Biotechnology.83: 435-445. 
23 Thiel, V., Leininger, S., Schmaljohann1, R., Brummer, F. and Imhoff, J.F. 2007. Sponge-specific Bacterial Associations of the Mediterranean Sponge Chondrilla nucula (Demospongiae, Tetractinomorpha). Microbial Ecology. 54: 101-111.

24 Tinambunan, H., Melki and Isnaini. 2012. Efektifitas Ekstrak Bakteri yang Berasosiasi dengan Spons dan Karang Lunak sebagai Antibakteri dari Perairan Pulau Tegal Lampung. Maspari Journal. 4 (2): 225-230.

25 Taylor, M.W., Radax, R., Steger, D. and Wagner, M. 2007. Sponge-Associated Microorganisms: Evolution, Ecology, and Biotechnological Potential. Microbiology Moleculer Biology Review. 71 (2): 295-347

26 Vasanthabharathi, V. and Jayalakshmi, S., 2012. Bioactive Potential of Symbiotic Bacteria and Fungi from Marine Sponges. African Journal of Biotechnology. 11 (29): 7500-7511

27 Yuhernitaand Juniarti. 2011.Analisis Senyawa Metabolit Sekunder dari Ekstrak Metanol Daun Surian yang Berpotensi sebagai Antioksidan.Makara Sains 15(1): 48-52

28 Zheng, L. 2005. Marine Bacteria Associated with Marine Macroorganisms: The Potential Antimicrobial Resources. Annals of Microbiology. 55 (2):119-124. 